IZA DP No. 3307

Tenure, Wage Profiles and Monitoring

J ohn Sessions

Nikolaos Theodoropoul os

J anuary 2008 


\title{
Tenure, Wage Profiles and Monitoring
}

\author{
John Sessions \\ University of Bath \\ and IZA \\ Nikolaos Theodoropoulos \\ University of Cyprus
}

Discussion Paper No. 3307
January 2008

IZA
P.O. Box 7240
53072 Bonn
Germany

Phone: +49-228-3894-0

Fax: +49-228-3894-180

E-mail: iza@iza.org

\begin{abstract}
Any opinions expressed here are those of the author(s) and not those of IZA. Research published in this series may include views on policy, but the institute itself takes no institutional policy positions.

The Institute for the Study of Labor (IZA) in Bonn is a local and virtual international research center and a place of communication between science, politics and business. IZA is an independent nonprofit organization supported by Deutsche Post World Net. The center is associated with the University of Bonn and offers a stimulating research environment through its international network, workshops and conferences, data service, project support, research visits and doctoral program. IZA engages in (i) original and internationally competitive research in all fields of labor economics, (ii) development of policy concepts, and (iii) dissemination of research results and concepts to the interested public.
\end{abstract}

IZA Discussion Papers often represent preliminary work and are circulated to encourage discussion. Citation of such a paper should account for its provisional character. A revised version may be available directly from the author. 
IZA Discussion Paper No. 3307

January 2008

\section{ABSTRACT}

\section{Tenure, Wage Profiles and Monitoring*}

We investigate the relationship between the slope of the wage-tenure profile and the level of monitoring across two cross sections of matched employer-employee British data. Our theoretical model predicts that increased monitoring leads to a decline in the slope of the wage-tenure profile. Our empirical analysis provides strong support for this prediction.

JEL Classification: J33, J41, J54

Keywords: monitoring, tenure, efficiency wages

Corresponding author:

John Sessions

Department of Economics \& International Development

University of Bath

Bath BA2 7AY

United Kingdom

E-mail: j.g.sessions@bath.ac.uk

\footnotetext{
* We are grateful to the ESRC Data Archive for supplying the 1998 and 2004 Workplace Employee Relations Survey and we thank J. Forth for help with the data. The normal disclaimer applies.
} 


\section{Introduction}

Efficiency wage theory predicts that firms can elicit effort from their employees by paying supra-competitive (i.e. efficiency) wages and/or by devoting resources to monitoring. This trade-off between the level of remuneration and monitoring has been examined extensively in the literature. Supportive evidence is found by Groshen and Krueger (1990), Rebitzer (1995), Krueger (1991), Kruse (1992), Ewing and Payne (1999). Unsupportive evidence is found by Neal (1993), Fitzroy and Kraft (1986) and Brunello (1995).

A third option available to the firm is to tilt the remuneration package over time such that the lure of higher future earnings acts as a deterrent to current shirking. The positive correlation between experience and earnings is one of the most robust and uncontentious findings in labour economics - for surveys of the literature, see Polachek and Siebert (1992) and Lazear (2000). It has long been observed that worker productivity is inexorably linked to the form of the compensation scheme [Mitchell et al. (1990)]. From the early work of Johnson (1950), Cheung (1969) and Ross (1973), a recurring theme of this literature is that the divergence of interests and the asymmetry of information between principal and agent cause output to depend upon the contingent nature of the compensation contract. The prohibitive cost of monitoring worker performance necessitates compensation schemes that induce workers to self-select behaviour the firm considers to be optimal. One method of doing this is to defer a substantial component of compensation until the later years of tenure. Such a wage profile provides a penalty for shirking and thereby encourages workers to work efficiently over their employment-cycle. Intuitively, by paying short-tenure workers less than their marginal product, and long-tenure workers conversely more, the firm is able to keep the present value of wages equal to the present value of productivity. This provides incentives to workers that would be absent if they were to be paid a wage that more closely followed 
productivity over their employment-cycle. Essentially, steep profiles provide ex post rents that the worker is reluctant to lose. If reducing effort increases the probability of involuntary termination, then steep profiles increase the cost of shirking, thereby encouraging workers to raise their effort level, and in this sense represent a form of efficiency wage payment [Lazear $(1979,1981)]$

The competing explanation for positive earnings profiles is derived from the general human capital model. This posits that workers become more productive, and hence better remunerated, over time on account of investments in human capital or training. Training investments can be either of a general, readily transferable variety or of a specific, nontransferable variety, both of which increase a worker's productivity over time in the current firm. The human capital thesis suggests that it is the return to this investment, with initial relatively low and subsequent relatively high real wages, which causes the earnings profile to have an upward slope [Becker (1975), Ben-Porath (1967), Mincer (1958, 1974)]. Wage growth is therefore equivalent to the return to investment in on-the-job training plus the change (i.e. reduction) in the investment from period to period minus any depreciation of the stock of human capital. Larger amounts of on-the-job training will result in steeper wage profiles. Recent work in this area has emphasised the plausibility of other explanations. For example, search models generally predict that more time in the labour marker increases the chance of finding a better match and thus tends to be associated with higher earnings [Burdett (1978), Ruhm (1991), Jacobson and LaLonde (1993), Manning (1997)]. Alternatively, workers may prefer rising earnings profiles as a form of forced saving [Loewenstein and Sicherman (1991), Frank and Hutchens (1993)].

In what follows we set out a simple, two-period model of efficiency wages that highlights the relationship between monitoring and the wage-tenure profile. The model suggests that there is a trade-off between current period monitoring and the slope of the 
profile. We then empirically test this prediction using a matched sample of British employeremployer data. Our aim is to answer what is, perhaps, one of the key questions in labour economics:

Personnel economics has grown over the past twenty years to become a major branch of labour economics. Although much has been learned, many important questions remain. For example, are worker wage profiles dependent on individual attributes or is the firm more important in determining wage growth. [Lazear (2000), p.611].

The paper is set out as follows: Section II outlines our theoretical model, Section III discusses our data and methodology, Section IV sets out our empirical results and Section V concludes.

\section{Theoretical Model}

Assume for ease of analytical exposition that workers are homogenous risk neutral with a working life of two periods and separable periodic utility functions $u_{t}=m_{t}-e_{t}, t=1$, 2 , where $m_{t}$ and $e_{t}$ denote income and effort respectively in period $t$. Assume further that employed workers make a discrete, all or nothing choice as regards the provision of effort to their employer such that $e_{t}=(0, \bar{e})$, where $\bar{e}>0$. The firm has access to some monitoring technology defined through the function $p(k)$, where $k$ denotes the value of resources devoted to monitoring and $p(k) \in[0,1]$ the probability that a shirker will be detected. To avoid unnecessary complications, we assume that the criteria on which this judgement is based are verifiable by an independent arbitrator such that there is no dispute about the firm's assessment. We assume $d p(k) / d k=p^{\prime}(k)>0, \quad d^{2} p(k) / d k^{2}=p^{\prime \prime}(k)<0, \quad p(0)=0$ and $p(\tilde{k})=1$. It is thus technically possible for the firm to perfectly monitor worker performance. Since our focus of interest is not the optimal level of monitoring, we assume that production and monitoring technologies are such that it is always in the interests of the 
firm to monitor imperfectly. Detection implies instantaneous dismissal and unemployment utility $b$.

The firm's problem is to maximize profits subject to the constraints that workers receives at least their reservation wage, $w^{r}=\bar{e}+b$, and that, once employed, they do not shirk. A 'spot-market' employment contract will therefore necessitate workers being paid the lowest wage that satisfies the single period 'non-shirking constraint' (NSC):

$w-\bar{e} \geq p(k) b+[1-p(k)] w$

Satisfaction of (1) implies an optimal (vis. 'efficiency') wage of $w^{*}=b+e / p>w^{r}$, such that workers receive some employment rents but are just indifferent between shirking and not shirking.

Now consider the specification of a two-period 'lifetime' contract $\left(w_{1}, w_{2}\right)$. In the second period of such a contract, the firm is faced with the same effort elicitation problem as those firms offering spot contracts such that $w_{2}^{*}=w^{*}=b+e / p$ as before. In the first period, however, the firm can set $w_{1}$ such that the worker's lifetime NSC is satisfied:

$$
w_{1}+w_{2}^{*}-2 \bar{e} \geq p(k) 2 b+[1-p(k)]\left(w_{1}+w_{2}^{*}-\bar{e}\right)
$$

Undetected shirkers enjoy utility of $w_{1}$ now and $w_{2}^{*}-\bar{e}$ tomorrow - i.e. given $w_{2}^{*}$, workers will not shirk in period 2. Note the assumption that detected shirkers are fired and forced into permanent unemployment. This is an expository device. Allowing a more realistic scenario whereby detected shirkers receive unemployment benefits in period one and then have a chance of obtaining a (single period) employment contract in period two would not change our qualitative results. Satisfaction of (2) implies an equilibrium period one wage of 
$w_{1}^{*}=b+\bar{e}$ such that workers employed under lifetime contracts face an upward sloping earnings profile:

$$
\Delta w^{*}=w_{2}^{*}-w_{1}^{*}=\left[\frac{1-p(k)}{p(k)}\right] \bar{e}>0
$$

Intuitively, workers acquire rents on account of the firm's inability to perfectly monitor. The firm, however, can reduce these rents by offering lifetime contracts that induce workers to queue up to access the second period wage that exceeds their reservation utility. It is apparent that increased monitoring on the part of the firm assuages the slope of this profile:

$$
\frac{\partial \Delta w}{\partial k}=-\frac{p^{\prime}(k)}{[p(k)]^{2}} \bar{e}<0
$$

There is thus a trade-off between the quantity of resources devoted to monitoring by the firm and the slope of the experience earnings profile.

\section{Data and Methodology}

Data

Our data are derived from the 1998 and 2004 Cross-Section Workplace Employee Relations Survey (WERS). These are the fourth and fifth instalments of a Government funded series of surveys conducted at British workplaces. The previous surveys were conducted in 1980, 1984 and 1990.

The sample of workplaces was randomly drawn from the Interdepartmental Business Register (IDBR). This is maintained by the Office for National Statistics (ONS) and is considered to be the highest quality sampling frame of workplaces available in the United Kingdom. The sample is stratified by workplace size and industry and larger workplaces and 
some industries are over represented [Chaplin et al. (2005)]. A workplace is defined as the activities of a single employer at a single set of premises.

The survey comprises three main sections; the 'Management Questionnaire’ (face-toface interviews with senior managers with day-to-day responsibility for employee relations), the 'Worker Representative Questionnaire’, and the 'Employee Questionnaire'. The survey population for the Management questionnaire is all British workplaces barring those in agriculture, hunting and forestry, fishing, mining and quarrying, private households with employed persons, and extra-territorial organisations.

The response rate in the 1998 (2004) Management Questionnaire was 80\% (64\%). The respective figure for the Employee Questionnaire was 66\% (61\%) [Airey et al. (1999) and Kersley et al. (2006) for reasons why the response rates differ]. At those workplaces responding to the manager survey, a questionnaire was presented to 25 randomly selected employees in workplaces with more than 25 employees or to all the employees in workplaces with fewer than 25 employees.

Changes in the nature of interest in employment relations led to substantial redesign of the 2004 wave. A major modification was the incorporation of small workplaces (i.e. those employing between 5 and 9 employees). There were also a number of changes to the format of the various survey questions [Kersley et al. (2006)].

For the purposes of our study we combine the data from the Management and Employee Questionnaires. Thus, our 1998 (2004) sample comprises 19578 (11270) employees linked to a set of 1744 (1509) establishments. Due to the stratified nature of the survey, we weight our estimates in order to be representative of the sampling population. Summary statistics of our variables of interest are presented in Tables 3a and 3b (Appendix).

\section{Methodology}

Our equation of interest is: 
$w_{i j}=\alpha+\beta_{0} t_{i j}+\beta_{1} t_{i j}^{2}+\beta_{2} m_{j}+\beta_{3}\left(t_{i j} \cdot m_{j}\right)+\beta_{4} \mathrm{X}_{i j}+u_{i j}$

where $i=1, \ldots, M$ and $j=1, \ldots, N$ denote individual worker and firm-specific subscripts respectively. The dependent variable, $w_{i j}$, denotes the log wage earned by individual $i$ at firm $j, t_{i j}$ denotes the employment tenure of individual $i$ at firm $j, m_{j}$ denotes the level of monitoring within firm $j, X_{i j}$ denotes a vector of individual regressors and $u_{i j}$ denotes the error term.

Following Leonard (1987), Gordon (1990, 1994) and Neal (1993), we proxy monitoring intensity via the proportion of supervisory employees within the firm. Supervisors, which include foremen and line managers, are defined in the WERS as 'those people directly concerned with the detailed supervision of work'. The specific survey variable (Binvmang) is derived from the following question asked in both the 1998 and 2004 'Management Questionnaire': 'What proportion of non-managerial employees here have job duties that involve supervising other employees?'. ${ }^{1}$ Managers were asked to indicate in which range their firm lay: 0\% (None), 1 - 19\% (Just a few), 20 - 39\% (Some), 40 - 59\% (Around half), 60 - 79\% (Most), 80 - 99\% (Almost all) and 100\% (All). From this information, we constructed a 7-point supervision index ('Monitoring') where 6 (0) represents the highest (lowest) level of monitoring. The distribution of the index across the sample of firms in 1998 (2004) is as follows: 0 [223 (263) firms], 1 [998 (880) firms], 2 [590 (625) firms], 3 [160 (175) firms], [84 (64) firms], 5 [47 (21) firms], and 6 [50 (15) firms]. ${ }^{2}$ Full variable

\footnotetext{
${ }^{1}$ In the 2004 survey, managers had the additional option of reporting the exact number of supervisors. One hundred and seven managers (4.7\% of the sample) did so. We have translated these responses back to percentages.

${ }^{2}$ Drago and Perlman (1989) support the use of supervision as a proxy for monitoring, although they acknowledge that supervision may occur for non-monitoring purposes - for example, to co-ordinate production. Indeed, monitoring may not entail direct supervision but may instead rely on factors such as output measurement and piece rates. More problematic, the number of supervisors might be high because monitoring is difficult [Allgulin and Ellingsen (2002)] or that supervisors only spend a fraction of work time monitoring
} 
definitions and summary statistics for the explanatory variables are detailed in Tables 1 and 2 in the Appendix.

We restrict our sample of employees in both the 1998 and 2004 surveys to nonmanagerial and non-professional workers, thereby ensuring that we do not conflate supervisors with managers. The 2004 survey, but not the 1998 survey, explicitly asks if an employee has supervisory responsibilities. The specific question is: 'Do you supervise any other employees? A supervisor, foremen or line manager is responsible for overseeing the work of other employees on a day to day basis.' (Answer: Yes; No). We drop these respondents from the sample. Cross tabulations indicate that these latter were overwhelmingly managerial and professional staff.

The discrete nature of our 'raw' monitoring variable renders statistical interpretation of its effect on the wage-tenure profile somewhat difficult. We therefore impute a continous value of monitoring for each firm in the sample by estimating a fitted version of (5):

$$
\begin{aligned}
& w_{i j}=\alpha+\beta_{0} t_{i j}+\beta_{1} t_{i j}^{2}+\beta_{2} \hat{m}_{j}+\beta_{3}\left(t_{i j} \cdot \hat{m}_{j}\right)+\beta_{4} X_{i j}+\varepsilon_{i j} \\
& \hat{m}_{j}=\beta_{5} \Theta_{j}+\delta_{j}
\end{aligned}
$$

$\hat{m}_{j}$ denotes the 'fitted' level of monitoring within firm $j$ and $\Theta_{j}$ is a vector of explanatory variables that influence this level of monitoring. ${ }^{3}$ We are thus able to infer from $\hat{\beta}_{3}$ the effect

[Rebitzer (1995)]. Despite these problems, the relative paucity of data compels us to rely on the proxy defined above. One exception is Kruse (1992) who proxies monitoring by an employee reported measure of how often the supervisor checks his work.

${ }^{3}$ We experimented with a number of firm-specific explanatory variables in estimating equation (7). Our results were robust to this experimentation and our preferred specification is that set out in Table 4 . 
on the profile of a unit increase in monitoring. We estimate equation (6) via a linear probability model, the results of which are set out in Table 4 (Appendix). ${ }^{4}$

Given the categorical nature of the wage variable, we estimate both (5) and (6) via an interval regression model. The actual question in both surveys is: 'How much do you get paid for your job here, before tax and other deductions are taken out? If your pay changes before tax from week to week because of overtime, or because you work different hours each week, think of what you earn on average. ${ }^{5}$

\section{Results}

Our results are set out in Tables 5 and 6 (Appendix). ${ }^{6}$ For each sample we run two different specifications. Both specifications include the same vector of control variables with the exception of our monitoring variable. The first specification includes the 'raw' monitoring variable (Monitoring) derived from Binvmang. The second specification includes the instrumented variable of monitoring (Fitted Monitoring).

Our results for both specifications across the two samples are consistent with the standard human capital model of wages and, for brevity, we do not discuss them. We instead focus on the salient feature of our empirical analysis, namely the relationship between monitoring and the shape of the wage-tenure profile. Considering Table 5, it is apparent that higher fitted monitoring (Fitted Monitorng) impacts negatively on the wage profile. Thus in

\footnotetext{
${ }^{4}$ We also estimate a fitted version of (5) using an ordered probit model to predict monitoring. Our results from this exercise remain qualitatively the same and are available on request.

${ }^{5}$ Respondents in the 1998 survey were asked to place their pay level within 12 bands, chosen to approximate decile bands and the top and bottom 5\% of the earnings distribution as estimated from the 1996 New Earnings Survey. The available bands were: less than $£ 50, £ 51-£ 80, £ 81-£ 140, £ 141-£ 180, £ 181-£ 220, £ 221-£ 260$, £261$£ 310, £ 311-£ 360, £ 361-£ 430, £ 431-£ 540, £ 541-£ 680, £ 681$ or more. The number of bands was increased to 14 in 2004: less than £50, £51-£80, £81-£110, £111-£140, £141-£180, £181-£220, £221-£260, £261-£310, £311$£ 360, £ 361-£ 430, £ 431-£ 540$, £541-£680, £681-£870, £871 or more. We construct lower and upper bounds of wages by taking the mid-points of each band and then aggregating.

${ }^{6}$ Our results for 2004 are based on a sample of all workplaces surveyed. Restricting the sample to establishments with more than 10 employees, in order to render the sample comparable with the 1998 sample, does not affect our results. These results are available from the authors on request.
} 
1998, a unit increase in Fitted Monitoring reduces the slope of the wage profile by 1.7 percent for each year of tenure. Considering Table 6, both Monitoring and Fitted Monitoring impact negatively on the wage-tenure profile. In 2004, a unit increase in Fitted Monitoring reduces the slope of the profile by 2.2 per cent for each year of tenure. Our results show that increased monitoring therefore not only reduces the slope of the wage tenure profile, but it does so more for employees with longer tenure.

Figures 1 to 4 illustrate wage-tenure profiles for the two estimated regressions across the two survey years. In Figure 1 and Figure 3 we simulate four wage-tenure profiles representing four values of our 'raw' monitoring variable (i.e. Monitoring $=0$, Monitoring $=$ 1, Monitoring = 3, Monitoring = 6). In Figure 2 and Figure 4 we simulate four wage-tenure profiles representing four values of our 'fitted' monitoring variable (i.e. Fitted Monitoring = 0, Fitted Monitoring $=$ Minimum, Fitted Monitoring $=$ Mean, Fitted Monitoring $=$ Maximum). The minimum, mean and maximum values of Fitted Monitoring for 1998 (2004) were 0.354 (0.229), $1.471(1.345)$ and $2.775(0.928)^{7}$

It is apparent from Figures 1 to 4 that despite controlling directly for human capital and demographic variables, and indirectly for a battery of firm-specific variables, there is a significant and consistent negative relationship between monitoring and the slope of the wage-tenure profile. In Figure 1, for example, wages peak at 13.2 years of tenure when Monitoring $=0$. When Monitoring $=1$, the peak occurs at 12.5 years, falling to 10.4 years and 8.3 years as Monitoring $=3$ and Monitoring $=6$ respectively. Our analysis thus suggests that firms are able to economise on future wage costs by devoting more resources to current period monitoring.

\footnotetext{
${ }^{7}$ Note that for ease of graphical exposition, we have set all constants to zero. This has the effect in some cases of generating a negative profile at certain levels of tenure. Profiles would remain positive if we set the constants equal to their estimated values from the regression results.
} 


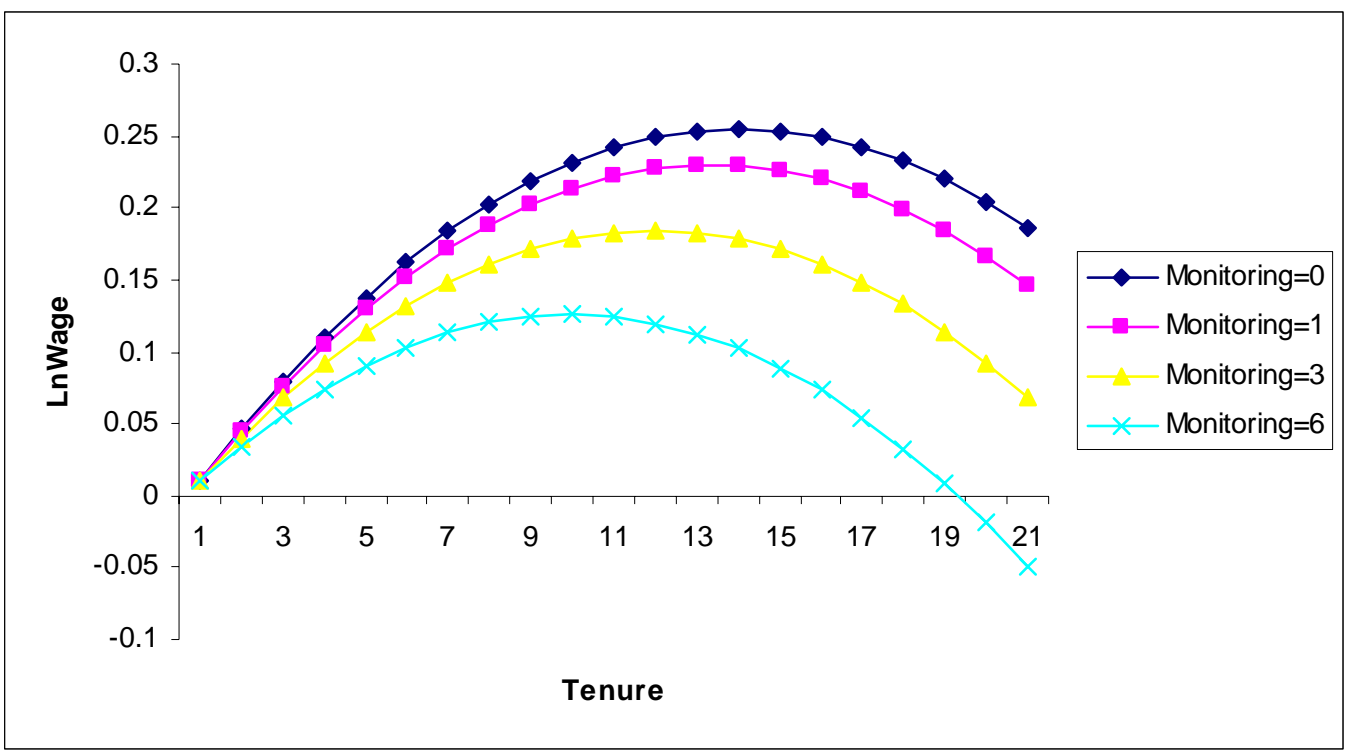

Figure 1: WERS 1998 - Monitoring

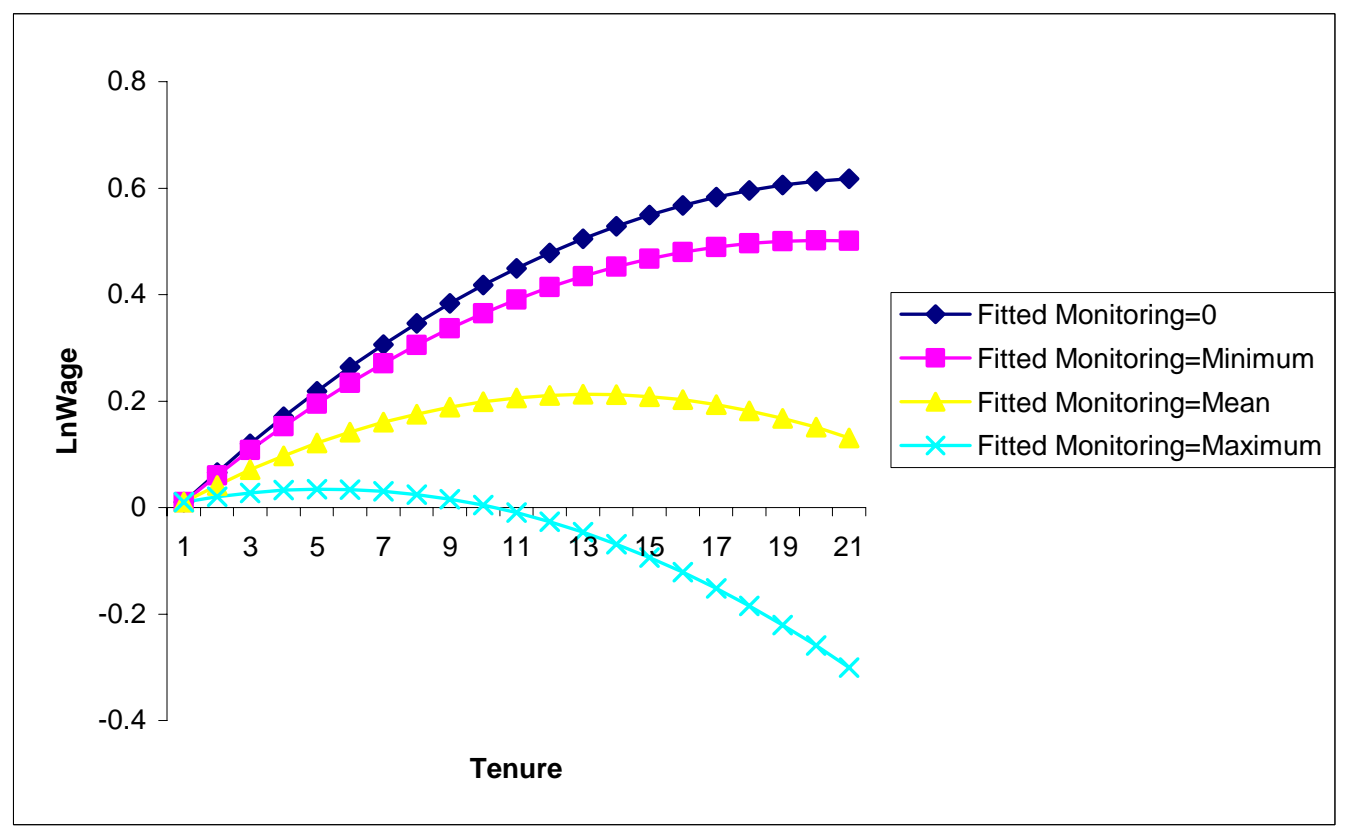

Figure 2: WERS 1998- Fitted Monitoring 


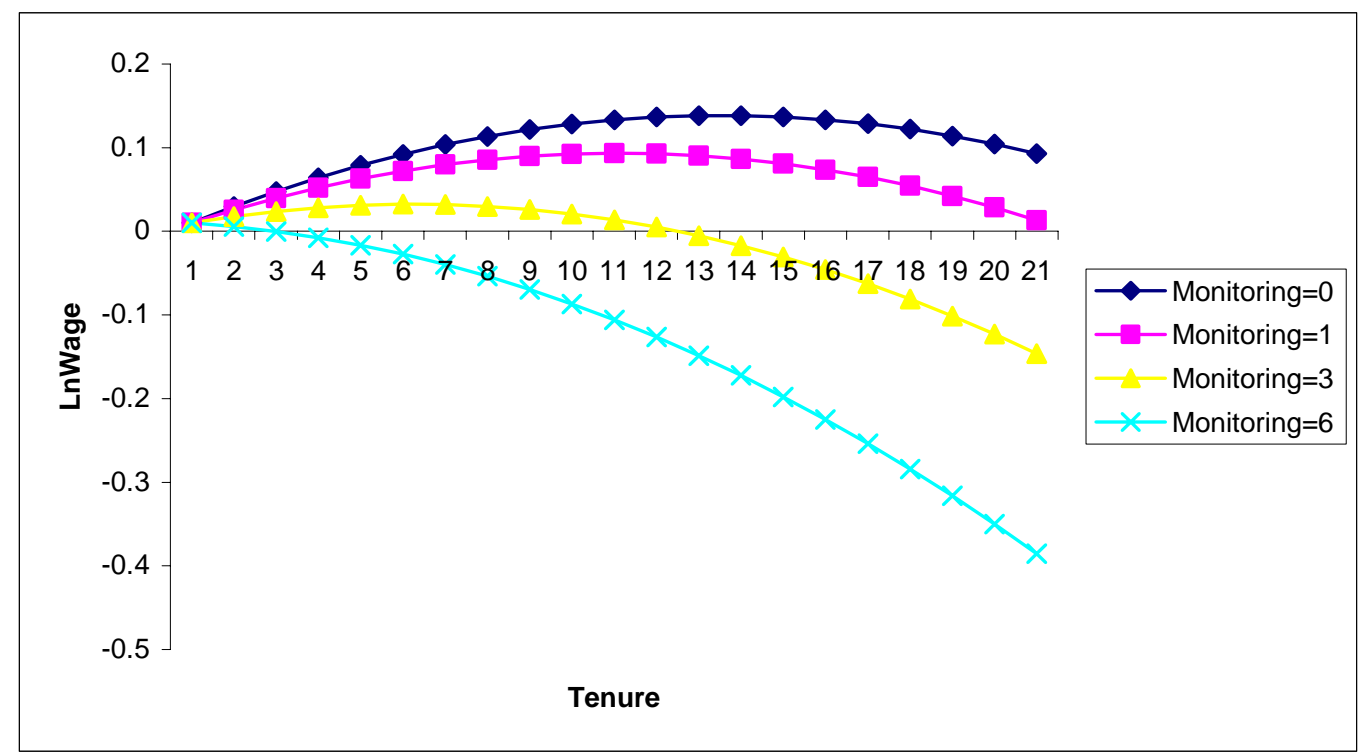

Figure 3: WERS 2004- Monitoring

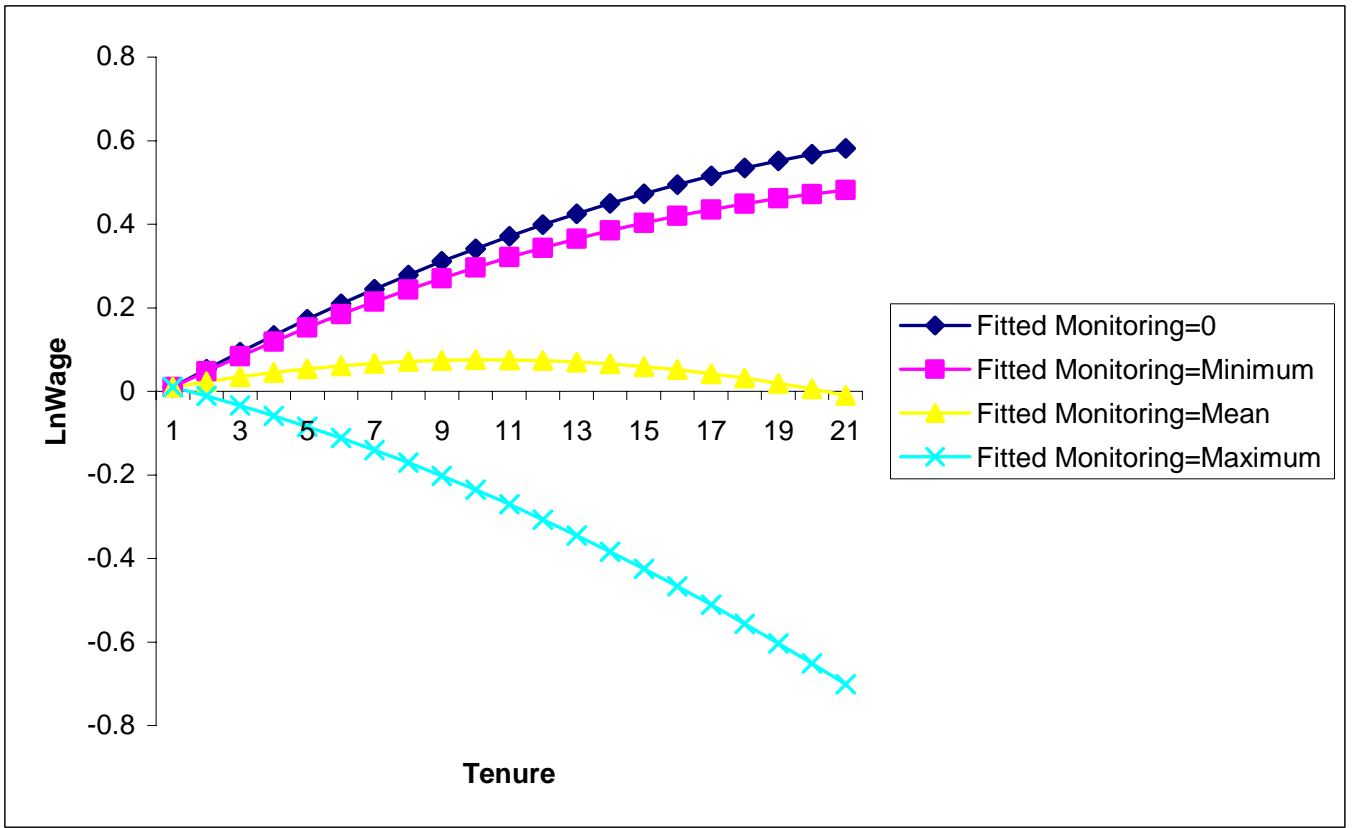

Figure 4: WERS 2004- Fitted Monitoring

Our results also exhibit an insignificant (positive) relationship between Monitoring (Fitted Monitoring) and LnWage in both 1998 and 2004. This is in line with the existing, somewhat ambiguous, evidence on the relationship between monitoring and wages [Goerke (2001), Walsh (1999)]. Increased levels of monitoring have been found to impact both positively and negatively on wages, with negative effects being found for high effort workers [Strobl and Walsh (2007)]. 


\section{Final Comments}

Efficiency wage theory predicts that firms can elicit effort from their employees by paying supra-competitive (i.e. efficiency) wages and/or by devoting resources to monitoring. Another option available to firms is to tilt the remuneration package over time such that the prospect of higher future earnings acts as a deterrent to current period shirking. It follows, therefore, that a potential trade-off, and one not hitherto investigated in the literature, is that between the level of monitoring and the shape of the wage-tenure profile.

We have explored these predictions using two cross-section surveys of matched employer-employee data for Britain. Our results suggest an inverse relationship between the level of monitoring and the slope of the wage-tenure profile, and may be interpreted as further evidence of efficiency wage theory. They also support the view that it is agency rather than human capital considerations that drive the wage-tenure profile. It would appear that British establishments elicit optimal effort from their employees by trading off higher current period monitoring against future wage rents. Whether or not this strategy is replicated by firms in other countries is an issue for future research. 


\section{Appendix}

Table 1: Variable List and Definitions - Employee Questionnaire

\begin{tabular}{|c|c|}
\hline Variable & Definition \\
\hline \multicolumn{2}{|c|}{ Individual Characteristics } \\
\hline Female & Female, (0/1) dummy \\
\hline Ethnicity & Ethnic minority: Black (Caribbean, African, other), Indian, Pakistani, Bangladeshi, Chinese, (0/1) dummy \\
\hline No married & Current marital status, (0/1) dummy \\
\hline Disabled & Long standing health problems or disabilities which limit work, home or leisure time, $(0 / 1)$ dummy \\
\hline \multicolumn{2}{|c|}{ Academic Qualifications } \\
\hline Low CSE & GCSE (grades $D-G),(0 / 1)$ dummy \\
\hline High CSE & GCSE (grades A-C), (0/1) dummy \\
\hline A-Level & A level or equivalent, (0/1) dummy \\
\hline Degree & Degree or equivalent, (0/1) dummy \\
\hline Postgraduate & Postgraduate degree or equivalent, (0/1) dummy \\
\hline Vocational & $\begin{array}{l}\text { Recognised vocational qualifications (i.e. trade apprenticeship, NVQs, City and Guilds Certificate), (0/1) } \\
\text { dummy }\end{array}$ \\
\hline \multicolumn{2}{|c|}{ Job Characteristics } \\
\hline LnWage & Log Average Gross Weekly Wages \\
\hline Lower & Log of lower bound of each of 12 wage bands, (14 bands in 2004) \\
\hline Upper & Log of upper bound of each of 12 wage bands, (14 bands in 2004) \\
\hline Tenure & Years at this workplace (mid-points of 5 bands) \\
\hline Tenure-Sq/100 & Tenure squared divided by 100 \\
\hline Fixed-Term & Employed on a fixed term contract, $(0 / 1)$ dummy \\
\hline Temporary & Employed on a temporary contract, $(0 / 1)$ dummy \\
\hline Union Member & Employee is a trade union member, $(0 / 1)$ dummy \\
\hline \multicolumn{2}{|c|}{ Occupational Categories } \\
\hline Technical & Associate professional and technical, (0/1) dummy \\
\hline Clerical & Clerical and secretarial (typist, postal clerk, secretary), (0/1) dummy \\
\hline Crafts & Craft and skilled service (tool maker, electrician, fitter), (0/1) dummy \\
\hline Services & Personal and protective service (police officer, bar staff), (0/1) dummy \\
\hline Sales & Sales (till operator, sales assistant), (0/1) dummy \\
\hline Operatives & Operative and assembly (assembly line worker, packer, truck driver), (0/1) dummy \\
\hline \multicolumn{2}{|c|}{ Training Dummies } \\
\hline Less than 1 day & Less than 1 day, (0/1) dummy \\
\hline 1 to less 2 days & 1 to less than 2 days, $(0 / 1)$ dummy \\
\hline 2 to less 5 days & 2 to less then 5 days, $(0 / 1)$ dummy \\
\hline 5 to less 10 days & 5 to less than 10 days, (0/1) dummy \\
\hline 10 days or more & 10 days or more, $(0 / 1)$ dummy \\
\hline
\end{tabular}


Table 2: Variable List and Definitions - Management Questionnaire

\begin{tabular}{|c|c|}
\hline Variable & Definition \\
\hline \multicolumn{2}{|l|}{ Establishment Characteristics } \\
\hline Monitoring & $\begin{array}{l}\% \text { of non-managerial employees who are supervisors vis: All (100\%), Almost all (80-99\%), } \\
\text { Most (60-89\%), Around half }(40-59 \%) \text {, Some }(20-39 \%) \text {, Just a few }(1-19 \%) \text {, None }(0 \%)\end{array}$ \\
\hline Lnsize & Log of the total number of employees at the establishment \\
\hline Percentage of part-time employees & $\%$ of part-time employees \\
\hline Percentage non-whites & $\%$ of employees from non-white ethnic background \\
\hline Trade union density & $\%$ of employees who are trade union members \\
\hline Percentage of dismissed employees & $\%$ of permanent employees who were dismissed the last 12 months (full and part time) \\
\hline Percentage of redundant employees & $\%$ of permanent employees who were made redundant the last 12 months (full and part time) \\
\hline \multicolumn{2}{|l|}{ Industry Classification } \\
\hline Manufacturing & Manufacturing, (0/1) dummy \\
\hline Utilities & Electricity, water, gas, (0/1) dummy \\
\hline Construction & Construction, (0/1) dummy \\
\hline Wholesale and retail & Wholesale and retail, (0/1) dummy \\
\hline Hotels and restaurants & Hotels and restaurants, (0/1) dummy \\
\hline Transportation & Transportation, (0/1) dummy \\
\hline Financial & Financial services, (0/1) dummy \\
\hline Other businesses & Other businesses, (0/1) dummy \\
\hline Public administration & Public administration, (0/1) dummy \\
\hline Education & Education, (0/1) dummy \\
\hline Health & Health, (0/1) dummy \\
\hline Regional Dummies & 10 region dummies (Standard Statistical Region) \\
\hline Teamwork Dummies & Dummy variables if employees work in formally designated teams \\
\hline Teamwork1 & Some-20-39\%, (0/1) dummy \\
\hline Teamwork2 & Just a few-1-39\%, (0/1) dummy \\
\hline Teamwork3 & None-0\%, (0/1) dummy \\
\hline Training dummies & $\begin{array}{l}\text { Percentage of experienced employees in the largest occupational group who have received } \\
\text { formal 'off-the-job' training over the past } 12 \text { months }\end{array}$ \\
\hline Training1 & Almost all,80-99\%, (0/1) dummy \\
\hline Training2 & Most,60-79\%, (0/1) dummy \\
\hline Training3 & Around half, 40-59\%, (0/1) dummy \\
\hline Training4 & Some, 20-39\%, (0/1) dummy \\
\hline Training5 & Just a few,1-19\%, (0/1) dummy \\
\hline Training6 & None, $0 \%,(0 / 1)$ dummy \\
\hline Average training in days & $\begin{array}{l}\text { Number of days experienced employees spend in formal off-the-job training sessions over } \\
\text { the past } 12 \text { months }\end{array}$ \\
\hline Days of training1 & No training, (0/1) dummy \\
\hline Days of training2 & Less than 1 day, (0/1) dummy \\
\hline Days of training3 & 1 to less than 2 days, (0/1) dummy \\
\hline Old establishment & $\begin{array}{l}\text { The establishment has been operating at current or previous address for more than } 5 \text { years } \\
(0 / 1) \text { dummy }\end{array}$ \\
\hline Pension scheme & Employees are entitled to an employer pension scheme, (0/1) dummy \\
\hline Market local & The establishment provides its goods and services to the local market, $(0 / 1)$ dummy \\
\hline Market regional & The establishment provides its goods and services to the regional market, (0/1) dummy \\
\hline Market national & The establishment provides its goods and services to the national market, $(0 / 1)$ dummy \\
\hline High competition & The degree of competition is very high/high, (0/1) dummy \\
\hline Ownership control1 & The establishment is UK owned/controlled, (0/1) dummy \\
\hline Ownership control2 & The establishment is predominantly UK owned (51\% or more), (0/1) dummy \\
\hline Ownership control3 & The establishment is UK and foreign owned, (0/1) dummy \\
\hline Ownership control4 & The establishment is predominantly foreign owned (51\% or more), (0/1) dummy \\
\hline Single establishment & Single independent establishment not belonging to another body, (0/1) dummy \\
\hline
\end{tabular}


Table 3a: Descriptive Statistics - Individual Questionnaire

\begin{tabular}{|c|c|c|c|c|}
\hline & \multicolumn{2}{|c|}{1998} & \multicolumn{2}{|c|}{2004} \\
\hline & Mean & Std. Deviation & Mean & Std. Deviation \\
\hline LnWage (lower) & 4.187 & 2.901 & 4.870 & 2.416 \\
\hline LnWage (upper) & 5.252 & 0.663 & 5.574 & 0.738 \\
\hline Tenure (years) & 6.532 & 5.496 & 8.806 & 5.363 \\
\hline Tenure-sq/100 & 0729. & 0.914 & 0.625 & 0.881 \\
\hline Fitted Monitoring & 1.471 & 0.353 & 1.350 & 0.392 \\
\hline Low CSE & 0.146 & 0.353 & 0.087 & 0.283 \\
\hline High CSE & 0.299 & 0.458 & 0.183 & 0.387 \\
\hline A-Level & 0.148 & 0.355 & 0.096 & 0.295 \\
\hline Degree & 0.073 & 0.260 & 0.097 & 0.295 \\
\hline Postgraduate & 0.101 & 0.102 & 0.023 & 0.150 \\
\hline Vocational & 0.368 & 0.482 & 0.555 & 0.497 \\
\hline Disabled & 0.065 & 0.247 & 0.116 & 0.321 \\
\hline Technical & 0.107 & 0.309 & 0.190 & 0.392 \\
\hline Clerk & 0.195 & 0.396 & 0.229 & 0.420 \\
\hline Craft & 0.131 & 0.338 & 0.104 & 0.305 \\
\hline Services & 0.103 & 0.303 & 0.090 & 0.286 \\
\hline Sales & 0.121 & 0.326 & 0.111 & 0.315 \\
\hline Operative & 0.162 & 0.369 & 0.115 & 0.318 \\
\hline Temporary job & 0.048 & 0.214 & 0.052 & 0.222 \\
\hline Fixed-term job & 0.027 & 0.163 & 0.026 & 0.159 \\
\hline Minority & 0.028 & 0.164 & 0.059 & 0.236 \\
\hline Female & 0.518 & 0.500 & 0.519 & 0.500 \\
\hline Trade union member & 0.388 & 0.487 & 0.304 & 0.460 \\
\hline No married & 0.237 & 0.425 & 0.249 & 0.432 \\
\hline Training (less than a day) & 0.103 & 0.305 & 0.101 & 0.301 \\
\hline Training ( 1 to less than 2 days) & 0.127 & 0.333 & 0.141 & 0.348 \\
\hline Training (2 to less than 5 days) & 0.160 & 0.367 & 0.189 & 0.392 \\
\hline Training (5 to less than 10 days) & 0.075 & 0.263 & 0.080 & 0.271 \\
\hline Training (10 days or more)) & 0.080 & 0.272 & 0.075 & 0.263 \\
\hline Number of Observations & \multicolumn{2}{|c|}{19578} & \multicolumn{2}{|c|}{11270} \\
\hline
\end{tabular}


Table 3b: Descriptive Statistics of Selective Establishment Characteristics ${ }^{1}$

\begin{tabular}{|c|c|c|c|c|}
\hline & \multicolumn{2}{|c|}{1998} & \multicolumn{2}{|c|}{2004} \\
\hline & Mean & Std. Dev & Mean & Std. Dev \\
\hline Size of the establishment ${ }^{2}$ & 72.375 & 238.982 & 47.140 & 139.313 \\
\hline Proportion part-time & 0.320 & 0.304 & 0.329 & 0.301 \\
\hline Union density & 0.257 & 0.332 & 0.193 & 0.313 \\
\hline Proportion of dismissals & 0.019 & 0.046 & 0.015 & 0.040 \\
\hline Proportion of redundancies & 0.018 & 0.144 & 0.008 & 0.036 \\
\hline Degree of competition in the market ${ }^{3}$ & 0.599 & 0.490 & 0.568 & 0.495 \\
\hline Single independent establishment & 0.311 & 0.463 & 0.302 & 0.459 \\
\hline Operating at this address $>5$ years & 0.905 & 0.293 & 0.920 & 0.271 \\
\hline Employer pension schemes & 0.678 & 0.467 & 0.681 & 0.466 \\
\hline Manufacturing & 0.156 & 0.363 & 0.129 & 0.335 \\
\hline Utilities $^{3}$ & 0.003 & 0.052 & 0.010 & 0.032 \\
\hline Construction & 0.037 & 0.190 & 0.035 & 0.184 \\
\hline Wholesale and retail & 0.199 & 0.400 & 0.205 & 0.404 \\
\hline Hotels and restaurants & 0.060 & 0.238 & 0.054 & 0.226 \\
\hline Transportation \& communication & 0.050 & 0.219 & 0.059 & 0.236 \\
\hline Financial services & 0.041 & 0.198 & 0.047 & 0.211 \\
\hline Other business services & 0.085 & 0.279 & 0.129 & 0.335 \\
\hline Public administration & 0.062 & 0.242 & 0.035 & 0.183 \\
\hline Education & 0.094 & 0.291 & 0.076 & 0.265 \\
\hline Health & 0.161 & 0.367 & 0.159 & 0.366 \\
\hline Other community services & 0.050 & 0.218 & 0.072 & 0.258 \\
\hline Number of observations & \multicolumn{2}{|c|}{19578} & \multicolumn{2}{|c|}{11270} \\
\hline
\end{tabular}

Notes: 1. Numbers are weighted; 2. Number of Employees; 3. Very High / High; 4. Electricity, Gas, Water. 
Table 4: Fitted Monitoring (Linear Probability Model)

Dependent Variable: Proportion of non-managerial employees supervising other employees. (Monitoring)

\begin{tabular}{|c|c|c|c|c|}
\hline & \multicolumn{2}{|c|}{1998} & \multicolumn{2}{|c|}{2004} \\
\hline & Coef & T-stat & Coef & T-stat \\
\hline Lnsize & 0.102 & 2.27 & 0.053 & 1.38 \\
\hline Part time proportion & -0.066 & -0.31 & -0.127 & -0.79 \\
\hline Percentage non-whites & -0.002 & -0.31 & -0.066 & -0.29 \\
\hline Trade union density & -0.254 & -1.52 & 0.077 & 0.37 \\
\hline Percentage of dismissals & -1.122 & -1.23 & 1.267 & 1.20 \\
\hline Percentage of redundancies & -0.162 & -1.49 & -1.082 & -1.75 \\
\hline Manufacturing & 0.146 & 0.55 & -0.073 & -0.36 \\
\hline Utilities & 0.032 & 0.11 & -0.336 & -1.08 \\
\hline Construction & 0.356 & 1.26 & 0.281 & 0.97 \\
\hline Wholesale & 0.148 & 0.55 & -0.131 & -0.73 \\
\hline Hotels and restaurants & -0.032 & -0.12 & -0.104 & -0.51 \\
\hline Transportation & -0.222 & -0.84 & -0.374 & -1.59 \\
\hline Financial services & -0.139 & -0.49 & -0.197 & -0.87 \\
\hline Other businesses & 0.111 & 0.40 & -0.166 & -0.91 \\
\hline Public administration & 0.130 & 0.47 & 0.037 & 0.08 \\
\hline Education & 0.293 & 1.08 & 0.447 & 2.03 \\
\hline Health & 0.024 & 0.09 & -0.062 & -0.35 \\
\hline Teamwork1 & -0.222 & -1.48 & -0.211 & -1.35 \\
\hline Teamwork2 & -0.375 & -2.50 & -0.149 & -1.04 \\
\hline Teamwork3 & -0.136 & -0.98 & -0.272 & -2.60 \\
\hline Training1 & -0.076 & -0.40 & 0.157 & 0.92 \\
\hline Training2 & 0.118 & 0.69 & 0.210 & 1.17 \\
\hline Training3 & 0.176 & 0.68 & 0.109 & 0.63 \\
\hline Training4 & -0.104 & -0.70 & 0.042 & 0.28 \\
\hline Training5 & -0.222 & -1.45 & -0.283 & -2.27 \\
\hline Training6 & -0.250 & -1.40 & -0.149 & -1.07 \\
\hline Days training1 & -0.839 & -2.71 & 0.342 & 1.00 \\
\hline Days training2 & -0.306 & -1.72 & 0.199 & 0.65 \\
\hline Days training3 & -0.172 & -1.65 & 0.036 & 0.34 \\
\hline Old establishment & -0.261 & -2.30 & -0.140 & -0.92 \\
\hline Pension scheme & -0.194 & -1.61 & -0.150 & -1.54 \\
\hline Market local & 0.005 & 0.04 & -0.284 & -2.31 \\
\hline Market regional & 0.007 & 0.04 & -0.159 & -1.01 \\
\hline Market national & 0.016 & 0.11 & -0.288 & -2.17 \\
\hline High competition & 0.009 & 0.08 & 0.095 & 0.91 \\
\hline Ownership control1 & -0.245 & -1.87 & 0.297 & 2.25 \\
\hline Ownership control2 & -0.063 & -0.24 & 0.527 & 2.37 \\
\hline Ownership control3 & -0.301 & -1.23 & 0.004 & 0.02 \\
\hline Ownership control4 & -0.225 & -0.64 & -0.097 & -0.51 \\
\hline Single establishment & -0.040 & -0.31 & -0.056 & -0.50 \\
\hline Regional Dummies & \multicolumn{2}{|c|}{ Yes } & \multicolumn{2}{|c|}{ Yes } \\
\hline Constant & 1.993 & 5.59 & 1.678 & 5.72 \\
\hline Sample Size & \multicolumn{2}{|c|}{2152} & \multicolumn{2}{|c|}{2043} \\
\hline
\end{tabular}

Note: Estimated are weighted 
Table 5: Interval Regression (1998)

Dependent Variable: LnWage

\begin{tabular}{|c|c|c|c|c|}
\hline & \multicolumn{2}{|c|}{ "Specification 1} & \multicolumn{2}{|c|}{ Specification 2} \\
\hline & Coeff & T-stat & Coeff & T-stat \\
\hline Tenure & 0.038 & 4.22 & 0.058 & 4.26 \\
\hline Tenure-squared/100 & -0.144 & -3.03 & -0.136 & -2.93 \\
\hline Monitoring & 0.020 & 1.17 & - & - \\
\hline Monitoring*Tenure & -0.002 & -1.24 & - & - \\
\hline Fitted Monitoring & - & - & 0.242 & 3.58 \\
\hline Fitted Monitoring*Tenure & - & - & -0.017 & -2.62 \\
\hline Low CSE & 0.074 & 2.90 & 0.076 & 2.98 \\
\hline High CSE & 0.122 & 4.47 & 0.122 & 4.51 \\
\hline A-Level & 0.155 & 4.79 & 0.159 & 5.03 \\
\hline Degree & 0.348 & 8.20 & 0.345 & 8.27 \\
\hline Postgraduate & 0.310 & 3.10 & 0.299 & 3.00 \\
\hline Vocational & 0.065 & 3.50 & 0.062 & 3.35 \\
\hline Disabled & -0.104 & -2.72 & -0.108 & -2.84 \\
\hline Technical & 0.559 & 12.35 & 0.548 & 12.41 \\
\hline Clerk & 0.578 & 17.38 & 0.573 & 17.57 \\
\hline Craft & 0.512 & 11.68 & 0.510 & 11.42 \\
\hline Services & 0.038 & 0.62 & 0.036 & 0.59 \\
\hline Sales & 0.036 & 0.65 & 0.049 & 0.90 \\
\hline Operative & 0.437 & 11.04 & 0.441 & 11.27 \\
\hline Temporary job & -0.435 & -7.69 & -0.436 & -7.74 \\
\hline Fixed-term job & -0.237 & -4.40 & -0.242 & -4.55 \\
\hline Minority & -0.029 & -0.55 & -0.034 & -0.62 \\
\hline Female & -0.533 & -18.15 & -0.532 & -18.25 \\
\hline Trade union member & 0.201 & 8.08 & 0.205 & 8.08 \\
\hline No married & -0.184 & -7.64 & -0.177 & -7.53 \\
\hline Training (less than a day) & -0.001 & -0.02 & -0.006 & -0.21 \\
\hline Training (1 to less than 2 days) & 0.072 & 2.72 & 0.067 & 2.55 \\
\hline Training (2 to less than 5 days) & 0.143 & 4.77 & 0.133 & 4.46 \\
\hline Training (5 to less than 10 days) & 0.224 & 6.13 & 0.210 & 5.91 \\
\hline Training (10 days or more) & 0.090 & 1.47 & 0.083 & 1.33 \\
\hline Constant & 4.690 & 82.20 & 4.368 & 39.34 \\
\hline Log Sigma & -0.600 & -27.45 & -0.606 & -28.26 \\
\hline Number of Observations & 19 & & 19 & \\
\hline Wald Chi-Sq & 1708 & & 1675 & \\
\hline Log Pseudo Likelihood & -339 & & -338 & \\
\hline
\end{tabular}

Notes: Estimates are weighted and allow for the clustering of employees within establishments. 
Table 6: Interval Regression (2004)

Dependent Variable: LnWage

\begin{tabular}{|c|c|c|c|c|}
\hline & \multicolumn{2}{|c|}{ Specification 1} & \multicolumn{2}{|c|}{ Specification 2} \\
\hline & Coeff & T-stat & Coeff & T-stat \\
\hline Tenure & 0.021 & 2.04 & 0.044 & 3.55 \\
\hline Tenure-squared/100 & -0.081 & -1.44 & -0.075 & -1.33 \\
\hline Monitoring & 0.029 & 1.62 & --- & --- \\
\hline Monitoring*Tenure & -0.004 & -2.02 & --- & --- \\
\hline Fitted Monitoring & --- & --- & 0.201 & 3.59 \\
\hline Fitted Monitoring*Tenure & --- & --- & -0.022 & -4.03 \\
\hline Low CSE & 0.064 & 1.72 & 0.056 & 1.53 \\
\hline High CSE & 0.001 & 0.03 & 0.000 & 0.01 \\
\hline A-Level & -0.070 & -1.61 & -0.072 & -1.67 \\
\hline Degree & 0.169 & 3.67 & 0.163 & 3.56 \\
\hline Postgraduate & 0.244 & 3.16 & 0.240 & 3.06 \\
\hline Vocational & 0.062 & 2.82 & 0.060 & 2.76 \\
\hline Disabled & 0.008 & 0.24 & 0.009 & 0.29 \\
\hline Technical & 0.778 & 12.62 & 0.777 & 12.63 \\
\hline Clerk & 0.632 & 12.90 & 0.632 & 12.93 \\
\hline Craft & 0.570 & 10.30 & 0.568 & 10.20 \\
\hline Services & 0.031 & 5.88 & 0.294 & 5.68 \\
\hline Sales & 0.177 & 2.77 & 0.196 & 3.13 \\
\hline Operative & 0.541 & 9.26 & 0.548 & 9.34 \\
\hline Temporary job & -0.465 & -7.95 & -0.459 & -7.86 \\
\hline Fixed-term job & -0.027 & -0.52 & -0.032 & -0.63 \\
\hline Minority & 0.087 & 1.69 & 0.075 & 1.53 \\
\hline Female & -0.505 & -16.61 & -0.502 & -16.67 \\
\hline Trade union member & 0.200 & 6.12 & 0.200 & 6.12 \\
\hline No married & -0.070 & -2.27 & -0.071 & -2.28 \\
\hline Training (less than a day) & -0.024 & -0.64 & -0.025 & -0.66 \\
\hline Training ( 1 to less than 2 days) & 0.118 & 2.82 & 0.119 & 2.85 \\
\hline Training (2 to less than 5 days) & 0.127 & 3.72 & 0.128 & 3.76 \\
\hline Training (5 to less than 10 days) & 0.219 & 5.07 & 0.222 & 5.19 \\
\hline Training (10 days or more) & 0.124 & 2.32 & 0.122 & 2.27 \\
\hline Constant & 4.880 & 85.43 & 4.650 & 50.24 \\
\hline Log Sigma & -0.497 & -22.25 & -0.500 & -22.58 \\
\hline Number of Observations & 112 & & 11 & \\
\hline Wald Chi-Sq & 1184 & & 1230 & \\
\hline Log Pseudo Likelihood & -776 & & -775 & \\
\hline
\end{tabular}

Notes: Estimates are weighted and allow for the clustering of employees within establishments. 


\section{References}

Airey, C., Hales, J., Hamilton, R., McKernan, A. and Purdon, S. (1999). The Workplace Employee Relations Survey, 1998 (WERS): 1998 Technical Report (cross section and panel samples), London: Social and Community Planning Research.

Becker, G. S. (1975). Human Capital. New York: Columbia University Press for National Bureau of Economic Research.

Ben-Porath, Y. (1967). 'The Production of Human Capital and the Life Cycle of Earnings.' Journal of Political Economy, Vol. 75, pp. 352-65.

Brunello, G. (1995). 'The Relationship between Supervision and Pay: Evidence from the British New Earnings Survey.' Oxford Bulletin of Economics and Statistics, Vol. 57, pp.309-22.

Burdett, K. (1978). ‘A Theory of Employee Job Search and Quit Rates.’ American Economic Review, Vol. 68, pp. 212-24.

Chaplin, J., Mangla, J., Purdon, S. and Airey, C. (2005). The Workplace Employment Relations Survey 2004 (WERS 2004) Technical Report (Cross Section and Panel Surveys), London: National Centre for Social Research.

Cheung, S. (1969). The Theory of Share Tenancy. Chicago: Chicago University Press.

Ewing, B. and J. Payne. (1999). 'The Trade-off between Supervision and Wages: Evidence of Efficiency Wages from the NLSY.' Southern Economic Journal, Vol. 66, pp. 424-32.

Fitzroy, F. and K. Kraft. (1986), 'Cooperation, Productivity and Profit Sharing.' Quarterly Journal of Economics, Vol. 102, pp.23-35.

Frank, R. H. and R. M. Hutchens. (1993). 'Wages, Seniority and the Demand for Rising Consumption Profiles.' Journal of Economic Behaviour and Organisation, Vol. 21, pp. 251-76.

Goerke, L. (2001). 'On the Relationship Between Wages and Monitoring in Shirking Models', Metroeconomica, Vol. 52, pp. 376-90.

Groshen, E. and A. Krueger. (1990). 'The Structure of Supervision and Pay in Hospitals.' Industrial and Labor Relations Review, Special Issue, Vol. 43, pp. 134S-46S.

Jacobson, L. and R. J. LaLonde. (1993).'Earnings Losses of Displaced Workers.' American Economic Review, Vol. 83, pp. 685-709.

Johnson, D. G. (1950). 'Resource Allocation under Share Contracts.' Journal of Political Economy, Vol. 58, pp. 111-23.

Kersley, B. Alpin, K. Forth, J. Bryson, A. Bewley, H. Dix, G. Oxenbridge, S. (2006). Inside the workplace: Findings from the 2004 Workplace Employment Relations Survey. Routledge.

Kruse, D. (1992) 'Supervision, Working Conditions and the Employer Size Effect.' Industrial Relations, Vol. 31, pp. 229-49.

Lazear, E. (2000). 'The Future of Personnel Economics.’ The Economic Journal, 110, F611-F639.

Lazear, E. P. (1979). 'Why is There Mandatory Retirement?’ Journal of Political Economy, Vol. 87, pp. 126184.

Lazear, E. P. (1981). 'Agency, Earnings Profiles, Productivity and Hours Restrictions.' American Economic Review, Vol. 71, pp. 606-20.

Manning, A. (1997). 'Mighty Good Thing: The Returns to Tenure.’ Mimeo, London School of Economics, CEP Discussion Paper No. 383.

Mincer, J. (1958). 'Investment in Human Capital and Personal Income Distribution.' Journal of Political Economy, Vol. 66, pp. 281-302.

Mincer, J. (1974). Schooling, Experience and Earnings. New York: Columbia University Press.

Mitchell, D. J. B, D. Lewin and E. E. Lawler III. (1990). 'Alternative Pay Systems, Firm Performance and Productivity.’. In A. Blinder, ed. Paying for Productivity: A Look at the Evidence. Washington, D.C.: The Brookings Institution.)

Neal, D. (1993). 'Supervision and Wages Across Industries.' Review of Economics and Statistics, Vol. 75, pp. 409-17.

Rebitzer, J. B. (1995). 'Is there a Trade-off between Supervision and Wages? An Empirical Test of Efficiency Wage Theory.' Journal of Economic Behavior and Organization, Vol. 28, pp. 107-29.

Ross, S. (1973). 'The Economic Theory of Agency.' American Economic Review, Vol. 63, pp. 134-39.

Ruhm, C. J. (1991). 'Are Workers Permanently Scarred by Job Displacements.' American Economic Review, Vol. 81, pp. 319-24.

Strobl, E. and Walsh, F. (2007). 'Estimating the Shirking Model with Variable Effort', Labour Economics, Vol. 14, pp. 623-37.

Walsh, F. (1999). ‘A Multisector Model of Efficiency Wages.’ Journal of Labour Economics, Vol. 17, pp. 35176. 